\title{
Scientometric trends of freshwater benthic invertebrates studies in Brazil
}

\author{
Cienciometria dos estudos de invertebrados bentônicos de água doce no Brasil
}

\author{
Ana Lúcia Brandimarte ${ }^{1 *}$ and Ana Liz Uchida Melo
}

${ }^{1}$ Departamento de Ecologia, Instituto de Biociências, Universidade de São Paulo - USP, Rua do Matão, 321, Travessa 14, Cidade Universitária, CEP 05508-900, São Paulo, SP, Brazil

${ }^{2}$ Departamento de Zoologia, Instituto de Biociências, Universidade Estadual Paulista - UNESP, Distrito de Rubiáo Júnior, s/n, CEP 18618-970, Botucatu, SP, Brazil

*e-mail: anabrand@ib.usp.br

Cite as: Brandimarte, A.L. and Melo, A.L.U. Scientometric trends of freshwater benthic invertebrates studies in Brazil. Acta Limnologica Brasiliensia, 2016, vol. 28, e20.

Abstract: Aim: The aim of this paper is to analyze trends in the literature concerning benthic invertebrates in Brazil, mainly the number of published papers and approaches used. Methods: The Ph.D. database of the Lattes Platform $(\mathrm{CNPq})$ was used as the source of information for the period 1970-2014. We searched for the terms "benthos", "macroinvertebrates", and "zoobenthos" in the titles and keywords of the papers listed on the platform. Papers were classified into the following categories: Systematics, Life History, Ecology, and Divulgation. These categories were further divided into subcategories. The percentage of papers in every major category and subcategory was calculated. Results: The search introduced 1,573 papers, which were mainly related to Ecology and Systematics. From 1970 to 2009, the number of papers published per decade increased exponentially, and the upward trend continues. The number of papers concerning Systematics, especially in Taxonomy, is increasing. Of the papers in Ecology category, those about Structure, Dynamics, and Distribution of the fauna have been increasing since the 1980s, and there has been an evident increase in the production of papers related to environmental damage in the last decade. The rate of production of papers concerning the role of invertebrates in ecosystems and the effects of different Spatial Scales has been increasing since the 2000s. Conclusion: There is a clear tendency towards the increased continuity of paper production concerning freshwater benthic invertebrates, and relatively new approaches as Conservation and Exotic Species are becoming relevant.

Keywords: paper production; systematics; life history; ecology; divulgation.

Resumo: Objetivo: Analisar a principais tendências relativas à produção de artigos relacionados a invertebrados bentônicos no Brasil, principalmente no que se refere ao número de trabalhos publicados e abordagens utilizadas. Métodos: A base de dados de doutores da Plataforma Lattes (CNPq) foi utilizada como a fonte de informaçáo para o período 1970-2012, usando-se os termos "bentos", "macroinvertebrados" e "zoobentos" constantes do título ou palavras chaves dos artigos científicos listados na plataforma. Os artigos citados nesta plataforma foram agrupados nas categorias: Sistemática, História de Vida, Ecologia e Divulgação, as quais foram divididas em subcategorias. Calculou-se a abundância relativa (\%) de categorias e subcategorias. Resultados: Foram analisados 1.573 artigos, os quais foram relacionados principalmente às categorias Ecologia e Sistemática. A produção de artigos aumentou exponencialmente de 1970 a 2009 e os dados posteriores mostram tendência de continuidade de tal aumento. Ainda há uma produção crescente sobre Sistemática, com dominância de artigos relacionados à Taxonomia. Dentro da categoria Ecologia, artigos sobre Estrutura, Dinâmica e 
Distribuição da fauna têm aumentado desde a década de 1980 e há um aumento evidente da produção relacionada a impactos ambientais na última década. A produção de artigos relacionados ao papel dos invertebrados nos ecossistemas e o efeito de diferentes Escalas Espaciais têm aumentado a partir da década de 2000. Conclusáo: Há uma clara tendência de continuidade do aumento da produção de artigos relacionados aos invertebrados bentônicos, com abordagens mais recentes, como Conservação e Espécies Exóticas, se tornando relevantes.

Palavras-chave: produção de artigos; sistemática; história de vida; ecologia; divulgação.

\section{Introduction}

Since science is a production system whose products are papers and other publications, it is possible to quantify its results (Spinak, 1998). The evaluative bibliometrics, i.e., the use of publication and citation analyses as indicators of science output, is one of the primary methods of science quantification (Drew et al., 2016).

The results of research are, in part, a product of the historical context. Therefore, any effort to analyze the papers on freshwater benthic invertebrates in Brazil should be based on the development of this science in that country. Only then it would be possible to understand the tendencies associated with paper production.

The earliest studies were mainly made by foreign researchers, among them Herman Kleerekoper (a Dutch scientist who made his studies in several Brazilian areas) and Ernst Fittkau (a German entomologist who was in Amazonia). Although he was not a benthologist, Kleerekoper reported on benthic invertebrates in the longitudinal zones of Mogi-Guaçu River in his essential book "Introdução ao Estudo da Limnologia” (Kleerekoper, 1944). In the same text, the author already made a reference to the relevance of the biota of reference sites to the assessment of pollution, an idea that is pivotal for current benthologists. Starting in the 1960s, Fittkau conducted ecological studies on Amazonian Chironomidae, publishing several papers on this topic (e.g., Fittkau, 1967, 1971). Nevertheless, the studies on freshwater benthic invertebrates were relatively sparse and only had a boost in the mid-1970s, when more Brazilian scientists were being trained, in part as a result of the creation of the early graduate courses in zoology. The Course of Biological Sciences (Entomology) of the Federal University of Paraná, created in 1969, was the first, followed by the Course of Zoology of the University of São Paulo in 1970.

The first coordinator (from 1970 to 1972) of the latter course was Claudio Froehlich, who had been studying the zoology of benthic insects, using immatures (mainly Plecoptera) since the 1960 s (e.g., Froehlich, 1960, 1969). In the 1970s,
Dr Froehlich supervised the graduate studies of Aristides de Almeida Rocha and Gisela Yuka Shimizu. Their master's and Ph.D. theses pioneered the use of benthic invertebrates as bioindicators of eutrophication in Brazilian reservoirs, but these works did not lead to publication. The master thesis of Giovanni Strixino, completed in 1971, was also supervised by Froehlich. In the early 1980s, Giovanni Strixino and Susana Trivinho Strixino were already producing papers about benthic invertebrates, more specifically Chironomidae (e.g., Strixino \& Trivinho-Strixino, 1982; Trivinho-Strixino \& Strixino, 1981). Also in the 1980s, people, such as Norma Würdig and Alice Takeda, who had not completed their graduate studies in freshwater ecosystems began to work in this area and over time became a reference among professionals working with freshwater benthic invertebrates. Dr Würdig completed her Ph.D. in 1984 studying ostracods in the lagoons of Rio Grande do Sul State, but in the late 1980s she began to publish papers on freshwater ostracodes (Würdig \& Freitas, 1988). Dr Takeda finished her Ph.D. in 1988 working with Spartina alterniflora, but she had already published her first work on freshwater benthos in 1990 (Takeda et al., 1990). The above-mentioned researchers were concentrated in Southeast and South regions of Brazil. In North region, the Swiss geneticist Ilse Walker, that begun to work in the INPA (National Institute of Amazon Researches) in 1976, also changed and directed her focus to the invertebrates, becoming a specialist on benthic food webs (e.g., Walker, 1978). Some relevant names were probably forgotten in this brief history about the start of studies on freshwater benthic invertebrates in Brazil. Clearly, this oversight did not diminish the importance of their contribution to the development of that area of study.

From that initial period, the number of Brazilian scientists dedicated to the freshwater zoobenthos increased substantially, and a considerable number of them were students of the previously cited people. This increase occurred simultaneously with the flourishing of graduate courses on the core areas of zoology and ecology in the country. We can use 
the data from the Brazilian Federal Agency for the Support and Evaluation of Graduate Education (CAPES, 2016) to get an idea about the rate of implementation of these courses. Between 1969 and 1981 , the number of graduate courses in zoology in Brazil reached ten. Twelve new courses were created between 1994 and 2003, and fifteen between 2012 and 2015. The core area of ecology, in turn, was stablished with five graduate courses in 1976 . New courses were added slowly until 2000, when they reached a total of seventeen. However, from 2004 until 2010, twenty new courses were created, and in 2015, the total reached fifty-six.

Considering the history of the research on benthic invertebrates in Brazil, this study uses evaluative biometrics to analyze the dominant trends in research based on the number of published papers and the approaches used.

\section{Material and Methods}

The Lattes Platform, i.e. the Brazilian data bank on science and technology production maintained by the National Council for Scientific and Technological Development (CNPq), was used as the source of information because it contains the greatest number of curricula vitae of Brazilian scientists other than foreign researchers working in Brazil.

Only the Ph.D. database was used, bearing in mind that papers published by masters, undergraduates, and technicians have a high probability of having a Ph.D. as coauthor, so those papers would also appear in the Ph.D. curricula. The search by subject for the terms "benthos", "macroinvertebrates", and "zoobenthos", each in turn (in Portuguese and English), in the paper title or keywords resulted in about 1,300 curricula to be analyzed for the period 1970-2014. We considered only people working in freshwater environments, leaving 280 curricula actually used (Table 1 ).

From the bibliographic production of each researcher, we used only the reports published in scientific journals, from now on denominate simply papers. First of all, these papers were distributed among four broad categories: Systematics, Life History, Ecology, and Divulgation. The three first categories were further classified into subcategories. Systematics was subdivided into a) Inventories/ Records/Occurrence/Lists, grouping papers that deal with inventories and lists of organisms, records of occurrence and geographic distribution of taxa; and b) Systematics/Taxonomy, including the description of species and studies involving phylogenetic relationships. Papers related to Life History were classified according to the subcategories a) Anatomy/ Biometry; b) Bionomy/Behaviour; c) Growth/Body Development; d) Physiology; and e) Reproduction/ Life Cycle. Finally, the broad category Ecology was subdivided into a) Bioindicators, related to the use of benthic macroinvertebrates as indicators of anthropic impacts; b) Conservation, relating benthic invertebrates and conservation degree of

Table 1. Names of researchers whose curricula were used in this paper.

\begin{tabular}{ll}
\hline Adauto de Souza Ribeiro & Leonardo Maltchik Garcia \\
Adriana Teresita Jorcin Delgado & Lívia Maria Fusari \\
Adriano Caliman Ferreira da Silva & Loraine André Isoldi \\
Adriano Sanches Melo & Luciana Carvalho Bezerra de Menezes \\
Afonso Pelli & Luciana Garcia Angonesi \\
Alaide Aparecida Fonseca Gessner & Luciane Ayres Peres \\
Alcimar do Lago Carvalho & Lúcio Cadaval Bedê \\
Alex Bager & Ludgero Cardoso Galli Vieira \\
Alex Pires de Oliveira Nuñer & Ludmilla Oliveira Ribeiro \\
Alexandre Giovanelli & Luís Fernando Marques Dorvillé \\
Alice Michiyo Takeda & Luis Mauricio Bini \\
Alois Eduard Schafer & Luiz Antonio Martinelli \\
Ana Asuncion Huamantinco Araujo & Luiz Henrique Ronchi \\
Ana Emilia Siegloch & Luiz Ubiratan Hepp \\
Ana Lúcia Brandimarte & Manoel Inácio Silva Filho \\
Ana Lucia Fonseca & Marcel Okamoto Tanaka \\
Ana Lucia Henriques de Oliveira & Marcel Rodrigo Cavallaro \\
Ana Lucia Suriani Affonso & Marcelo da Silva Moretti \\
Analu Egydio dos Santos & Marcelo Luiz de Souza \\
Anderson Ferreira & Marcia Divina de Oliveira \\
André Rinaldo Senna Garraffoni & Márcia Regina Russo \\
André Trevisan & Marcia Regina Spies \\
Andréa Bialetzki & Márcia Santos de Menezes \\
Andréa Lúcia Teixeira de Souza & Marcia Thais Suriano \\
Andrea Novelli & Marcos Callisto de Faria Pereira \\
\hline
\end{tabular}


Table 1. Continued...

Andreia Aparecida Guimarães Strohschoen

Angela Manzolillo Sanseverino

Anna Paula Luzia

Antonio Fernando Monteiro Camargo

Björn Gücker

Bruce Rider Forsberg

Bruno Spacek Godoy

Carla Bender Kotzian

Carla Ferreira Rezende

Carlos Edwar de Carvalho Freitas

Carlos Rafael Lugo-Ortiz

Carolina Bittencourt de Abreu

Carolina Buso Dornfeld

Carolina Coelho Sokolowicz

Caroline Silva Neubern de Oliveira

Cecilia Volkmer-Ribeiro

Celio Ubirajara Magalhaes Filho

Cesar João Benetti

Christiane Heemann

Claudenice Moreira dos Santos

Claudia Eiko Yoshida

Claudia Padovesi Fonseca

Claudia Tasso Callil

Claudio Gilberto Froehlich

Cleber Palma Silva

Colin Robert Beasley

Cristina Márcia de Menezes Butakka

Cristina Stenert

Daniel de Brito Fragoso

Daniel Forsin Buss

Daniela Cambeses Pareschi

Daniela Maeda Takiya

Daniele Sayuri Fujita

Danielle Anjos dos Santos

Darcilio Fernandes Baptista

Dayse Lucy Medeiros Carneiro Resende

Demétrio Luis Guadagnin

Domingos Sávio Barbosa

Douglas Fernando Peiró

Ednilson Paulino Queiroz

Eduardo Cargnin Ferreira

Eduardo Perico

Elidiomar Ribeiro da Silva

Elisa YokoyamaLisandro

Elisete Ana Barp

Elvio Sergio Figueredo Medeiros

Elynton Alves do Nascimento

Emerson Machado de Carvalho

Eneida Maria Eskinazi Sant'Anna

Enrique Querol Chiva

Erlei Cassiano Keppeler

Eudes de Souza Correia

Eustáquio José Machado

Evanilde Benedito

Evelise Nunes Fragoso de Moura

Fabiana Schneck

Fabiano Botta Tonissi

Fabio de Oliveira Roque

Fabio Kiyohara

Fabio Laurindo da Silva

Fábio Ricardo da Rosa

Flavio da Costa Fernandes

Francisco Antonio Rodrigues Barbosa

Francisco de Assis Esteves

Francisco José Pegado Abílio

Frederico Falcão Salles

Gabriel de Paula Paciencia

Geuza Cantanhêde da Silva
Marcos Gomes Nogueira

Marcos Paulo Figueiredo de Barros

Marcus Vinicius Morini Querol

Margarida Flores Roza-Gomes

Maria Alice Penna Firme dos Santos

Maria Cristina Dreher Mansur

Maria Cristina Pons da Silva

Maria da Conceição Tavares Frigo

Maria do Carmo Calijuri

Maria José do Nascimento Ferreira

Maria Julia Martins Silva

Maria Margarida Granate Sá e Melo Marques

Maria Paula Delicio

Maria Virginia Urso-Guimaraes

Mariana Egler

Mariana Silveira Guerra Moura e Silva

Marilza Maia Herzog

Mario Antonio Navarro da Silva

Mario Donizeti Domingos

Marlene Sofia Arcifa

Marlus Bueno Silva

Mateus Pepinelli

Maurea Nicoletti Flynn

Mauricio Anaya

Mauricio Camargo-Zorro

Maurício Lopes de Faria

Mauricio Mello Petrucio

Mauricio Pereira Almerão

Milton Norberto Strieder

Mônica Ceneviva Bastos

Monica de Cassia Souza Campos

Monica Luisa Kuhlmann

Mônica Mungai Chacur

Nadja Gomes Machado

Nelson Ferreira Junior

Neusa Hamada

Nilza Cristina Buttow

Norma Luiza Würdig

Odete Rocha

Odila Rigolin de Sa

Oswaldo Campos Junior

Otávio Froehlich

Otoniel Geter Lauz Ferreira

Pablo Moreno Souza Paula

Paulina Maria Maia Barbosa

Paulino Barroso Medina Júnior

Paulo Augusto Zaitune Pamplin

Paulo De Marco Júnior

Paulo Henrique Costa Corgosinho

Paulo Roberto Pagliosa Alves

Paulo Roberto Pereira de Araujo

Pedro Antonio Zagatto

Péricles Leonardo Fernandes

Pitágoras da Conceição Bispo

Plínio Barbosa de Camargo

Raoul Henry

Raphael Ligeiro Barroso Santos

Regina Mayumi Kikuchi

Reinaldo Luiz Bozelli

Ricardo Marcelo Geraldi

Riccardo Mugnai

Rita de Cassia Farani Assis

Roberta Sebastiany França

Roberta Zani da Silva

Roberto da Gama Alves

Roberto de Moraes Lima Silveira

Roberto Munehisa Shimizu

Rodrigo König 
Table 1. Continued...

\author{
Gilza Maria de Souza-Franco \\ Giovanni Battista Mario Aldo Strixino \\ Gisela Yuka Shimizu \\ Gisele Luziane de Almeida \\ Giuliano Buzá Jacobucci \\ Graziele Wolff de Almeida Carvalho \\ Guilherme Rossi Gorni \\ Guilherme Schnell e Schühli \\ Heliana Rosely Neves Oliveira \\ Hélio Gerso Konrad \\ Henrique Paprocki \\ Herbet Tadeu de Almeida Andrade \\ Humberto Fonseca Mendes \\ Inga Ludmila Veitenheimer Mendes \\ Ivana de Freitas Barbola \\ Jandira Liria Biscalquini Talamoni \\ Janet Higuti \\ Janine Oliveira Arruda \\ Jansen Fernandes de Medeiros \\ Jean Pierre Henry Balbaud Ometto \\ Jelly Makoto Nakagaki \\ João Ânderson Fulan \\ Joao Jose Fonseca Leal \\ Joel Augusto Muniz \\ Jorge Luiz Nessimian \\ Jose Carlos Nascimento de Barros \\ José Eloy dos Santos Júnior \\ José Francisco Gonçalves Júnior \\ José Lopes \\ José Marcelo Rocha Aranha \\ José Moacir Ferreira Ribeiro \\ José Reinaldo Pacheco Pelej \\ José Souto Rosa Filho \\ José Valdecir de Lucca \\ Joseline Molozzi \\ Judith Font Batalla \\ Juliana Simião Ferreira \\ Juliano José Corbi \\ Julio Ferraz de Queiroz \\ Juno Soares Vieira \\ Karina Ocampo Righi Cavallaro \\ Karine Delevati Colpo \\ Karl Matthias Wantzen \\ Kathia Cristhina Sonoda Braga \\ Kennedy Francis Roche \\ Leandro Gonçalves Oliveira \\ Leny Célia da Silva Correia
}

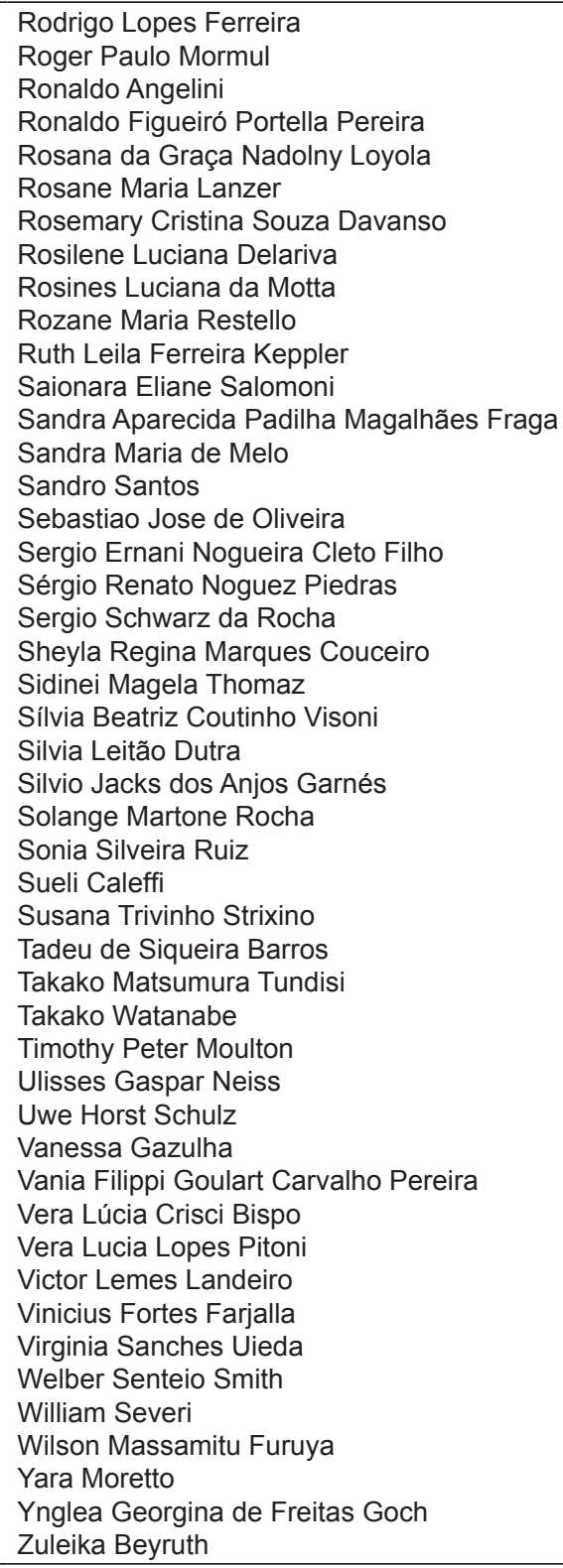

aquatic and terrestrial ecosystems; c) Exotic Species, besides the effect of occurrence of non-native species in ecosystems could be included in other categories, e.g., Conservation, we prefer to maintain a specific subcategory due to the increasing introduction and effects of exotic species worldwide; d) Feeding Habits/Trophic Relationships/Food Chains and Webs, including the papers related to dietary issues; e) Other Interactions/Associations, dealing with relationships which do not involve trophic interaction; f) Methodology, grouping papers about sampling of organisms and other methodologic issues; g) Paleolimnology; h) Processes, related to the role of benthic invertebrates in the functioning of ecosystems (e.g., in the detritus degradation); i) Spatial Scales, related specifically to the comparison of the effect of different scales on the benthic community; j) Structure/Dynamic/ Distribution, including papers about composition, density, biomass, richness and diversity of organisms, and temporal and spatial changes in the structure of populations or communities; k) Toxicology, including the use of benthic invertebrates in ecotoxicological studies; l) Volunteer Monitoring, grouping papers related to the use of benthic invertebrates as indicators of water quality by volunteer people; and m) Other Approaches (e.g., 
factors that affect the colonization by benthic organisms).

We calculated the relative abundance (\%) of categories to the total of papers and the subcategories to the total in each category.

\section{Results and Discussion}

As in other countries, the Brazilian science development depends broadly on the governmental policies and support for science and technology. There are two major national institutions related to this subject in the country, both of them created in 1951. The National Council for Scientific and Technological Development (CNPq) aims to foster and foment scientific and technological development, as well as contributing to the formulation of national policies of science and technology. An interesting record of the history of CNPq genesis can be found in Motoyama (1985). Besides supplying funds and grants to research, as does CNPq, the Federal Agency for the Support and Evaluation of Graduate Education (CAPES) has an important role in the expansion and consolidation of stricto sensu graduate courses. In 1995, CAPES was restructured and became responsible for the following and evaluation of those courses (CAPES, 2008). In this sense, the increased number of graduate courses in zoology and ecology, mainly from the middle of the 1990's till now, came out of the joint efforts of CAPES and Brazilian universities. Moreover, Brazilian states have their research foundations that also provide researchers with funds and grants. Among them, FAPESP in São Paulo State (1960) and FAPERGS in the Rio Grande do Sul State (1964) are the oldest. The work of all these institutions contributed to the increase of scientists in Brazil, among them a large number of people studying benthic invertebrates.

On to the scientific production of those professionals, we analyzed 1,573 papers published between 1970 and 2014 that were mainly related to Ecology and Systematics (Figure 1). From 1970 to 2009, paper production increased exponentially (Figure 2). Moreover, in the period from 2010 to 2014 the total of published papers already amounted to circa $70 \%(68.2 \%)$ of the production of the decade from 2000 to 2009 . The increase of paper publication became more marked from the 1990 s, reflecting the increasing support for the science in Brazil from that time onwards.

On relation to the different categories of papers, we suspected that the production of Life History papers had been underestimated. Possibly, a considerable number of authors working on that issue were not using the terms "benthos", "macroinvertebrates", or "zoobenthos" in their papers. The same could be true of papers related to Systematics. Nevertheless, there has been an increasing production of papers on Systematics, with most of the papers focusing on Taxonomy (Table 2). This fact demonstrates that the knowledge about freshwater benthic invertebrate fauna is still incomplete in Brazil, and we need to continue hardly working on this issue.

Concerning the category Ecology, although scientific works associating benthic invertebrates and environmental changes have been performed since the 1970s, the production of papers related to this issue only had an evident increase in the 2000s. This fact becomes especially apparent by the increase in papers on Conservation, Exotic species, and the use of invertebrates as Bioindicators (Table 2). With the increased impact on waterbodies we found an increased use of benthic invertebrates as indicators and correlated papers about them. Another consequence was the concern with the aquatic biota conservation, including those invertebrates. The increment on papers about Conservation is in part a result of the increase of professionals concerned about it and prepared

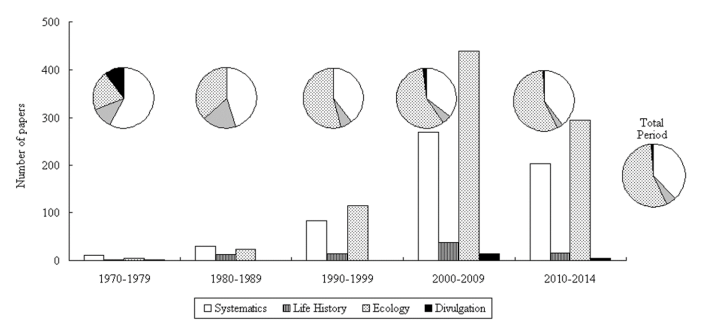

Figure 1. Numbers and relative abundance of papers published per decade (excepting the 2010-2014 period), concerning the broad categories of studies in freshwater benthic invertebrates in Brazil.

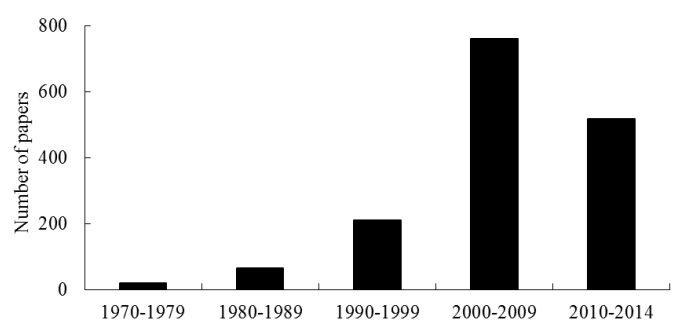

Figure 2. Total production of papers concerning freshwater benthic invertebrates per decade (excepting the 2010-2014 period) in Brazil. 
to deal with this issue, but there is also a rising demand to solve environmental problems related to habitat degradation, coupling the stoppage or minimization of impact and habitat restoring. Moreover, conservation and exotic species are closely related issues. Since new records of exotic species are increasing in Brazil, so is the knowledge about their impacts on native biota, and more papers about non-native species are being produced.

In the last decades, the scope of the scientific approaches used for benthic invertebrates is expanding. Papers concerning the role of invertebrates in Food Chains and Webs and other Processes in the ecosystems are achieving greater relevance since the 2000 s, though still with a low relative abundance. The same is true for papers on the effects of different Spatial Scales. Despite this shift in approach, traditional descriptive papers, such as those concerning local Structure, Dynamics, and Distribution of fauna, are numerous and growing in number (Table 2). Sometimes these papers are considered to be regionally constrained and without interest to be published in high impact journals, which could be discouraging for some researchers. However, they continue to be important because Brazilian freshwater benthic fauna is still barely known, and now we cannot set aside these approaches as our counterparts in developed countries. The increase in the number of papers related to Divulgation since the 2000s (Table 2) followed the popularization of science. However, this production remains modest, showing that perhaps Brazilian benthologists have only recently woken up to the relevance of informing about benthic invertebrates and their role in aquatic environments. In this sense, our delay in the use of volunteer biomonitoring is also comprehensible. In other countries, the role of volunteers in the monitoring of freshwaters is recognized for decades. In the U.S., e.g., volunteer practices have been in use since the 1990s and the Environmental Protection Agency considers that data gathered by volunteers can be used in state reports on the environmental quality of water bodies (USEPA, 1997). However, though studies using bioindicators began in the 1970s in Brazil, papers concerning the use of volunteer data arose only over the last five years covered by this research (e.g., Buss, 2008; França \& Callisto, 2012).

This paper presented the first attempt of scientometric analysis of papers concerning freshwater benthic invertebrates in Brazil. Further research should seek refinements, such as the categorization of papers by environment (e.g., lentic/lotic; lakes/reservoirs/rivers/streams), organization levels (e.g., individuals, populations,

Table 2. Numbers and relative abundance (parentheses) of four broad categories of papers concerning Brazilian benthic invertebrates from 1970 to 2014 .

\begin{tabular}{|c|c|c|c|c|c|c|}
\hline & & $1970-1979$ & $1980-1989$ & $1990-1999$ & $2000-2009$ & $2010-2014$ \\
\hline \multirow{13}{*}{ ECOLOGY } & Bioindicators & $0(0.0)$ & $3(12.5)$ & $28(24.6)$ & $96(21.9)$ & $75(25.5)$ \\
\hline & Conservation & $0(0.0)$ & $0(0.0)$ & $0(0.0)$ & $5(1.1)$ & $14(4.8)$ \\
\hline & Exotic species & $0(0.0)$ & $2(8.3)$ & $2(1.8)$ & $33(7.5)$ & $19(6.5)$ \\
\hline & $\begin{array}{l}\text { Feeding habits/Trophic } \\
\text { relationships/Food chains and } \\
\text { webs }\end{array}$ & $1(25.0)$ & $1(4.2)$ & $9(7.9)$ & $34(7.7)$ & $14(4.8)$ \\
\hline & Other interactions/Associations & $2(50.0)$ & $0(0.0)$ & $3(2.6)$ & $14(3.2)$ & $5(1.7)$ \\
\hline & Methodology & $0(0.0)$ & $1(4.2)$ & $8(7.0)$ & $32(7.3)$ & $21(7.1)$ \\
\hline & Paleolimnology & $0(0.0)$ & $0(0.0)$ & $3(2.6)$ & $6(1.4)$ & $0(0.0)$ \\
\hline & Processes & $0(0.0)$ & $0(0.0)$ & $2(1.8)$ & $35(8.0)$ & $27(9.2)$ \\
\hline & Spatial scales & $0(0.0)$ & $0(0.0)$ & $0(0.0)$ & $4(0.9)$ & $10(3.4)$ \\
\hline & Structure/Dynamic/Distribution & $0(0.0)$ & $12(50.0)$ & $48(42.1)$ & $125(28.5)$ & $75(25.5)$ \\
\hline & Toxicology & $0(0.0)$ & $0(0.0)$ & $0(0.0)$ & $10(2.3)$ & $4(1.4)$ \\
\hline & Volunteer monitoring & $0(0.0)$ & $0(0.0)$ & $0(0.0)$ & $0(0.0)$ & $3(1.0)$ \\
\hline & Other approaches & $1(25.0)$ & $5(20.8)$ & $11(9.6)$ & $45(10.3)$ & $27(9.2)$ \\
\hline \multirow[t]{2}{*}{ SYSTEMATICS } & $\begin{array}{l}\text { Inventories/Records/ } \\
\text { Occurrence/Lists }\end{array}$ & $4(36.4)$ & $6(20.7)$ & $24(28.9)$ & $55(20.4)$ & $40(19.6)$ \\
\hline & Systematics/Taxonomy & $7(63.6)$ & $23(79.3$ & $29(71.1)$ & $215(79.6)$ & $164(80.4)$ \\
\hline \multirow{5}{*}{ LIFE HISTORY } & Anatomy/Biometry & $2(100.0)$ & $2(16.7)$ & $6(42.9)$ & $14(37.8)$ & $6(37.5)$ \\
\hline & Bionomy/Behaviour & $0(0.0)$ & $0(0.0)$ & $1(7.1)$ & $5(13.5)$ & $5(31.3)$ \\
\hline & Growth/Body development & $0(0.0)$ & $7(58.3)$ & $4(28.6)$ & $9(24.3)$ & $2(12.5)$ \\
\hline & Fisiology & $0(0.0)$ & $0(0.0)$ & $1(7.1)$ & $1(2.7)$ & $0(0.0)$ \\
\hline & Reproduction/Life cycle & $0(0.0)$ & $3(25.0)$ & $2(14.3)$ & $8(21.6)$ & $3(18.8)$ \\
\hline DIVULGATION & Total & 2 & 0 & 0 & 14 & 4 \\
\hline
\end{tabular}


communities), geographic area (as new research groups are arising out of the South and Southeastern regions where the researchers are concentrated), dissemination (e.g., national or international journal, open or no open access journal, citation index), impact (e.g., the impact factor of each publication area) and collaboration networks. As there is relevant information published in books and chapters, these data could also be included.

\section{Acknowledgements}

Authors are grateful to anonymous referees whose suggestions greatly improved the paper.

\section{References}

BUSS, D.F. Desenvolvimento de um índice biológico para use de voluntários na avaliação da qualidade da água de rios. Oecologia Brasiliensis, 2008, 12, 516-526.

COORDENAÇÃO DE APERFEIÇOAMENTO DE PESSOAL DE NÍVEL SUPERIOR - CAPES. História e missão. Brasília: CAPES, 2008 [viewed 19 June 2016]. Available from: http://www.capes. gov.br/historia-e-missao

COORDENAÇÃO DE APERFEIÇOAMENTO DE PESSOAL DE NÍVEL SUPERIOR - CAPES. Pataforma Sucupira. Brasília: CAPES, 2016 [viewed 19 Apr. 2016]. Available from: https://sucupira. capes.gov.br/sucupira/public/informacoes_ programa/informacoesPrograma.jsf

DREW, C.H., PETTIBONE, K.G., FINCH 3rd., F.O., GILES, D. and JORDAN, P. Automated research impact assessment: a new bibliometrics approach. Scientometrics, 2016, 106(3), 987-1005. PMid:26989272. http://dx.doi.org/10.1007/ s11192-015-1828-7.

FITTKAU, E.J. On the ecology of Amazonian rainforest streams. In H Lent, ed. Atas do Simpósio sobre Biota Amazônica. Rio de Janeiro: Conselho Nacional de Pesquisas, 1967, pp. 97-108, vol. 3.

FITTKAU, E.J. Distribution and ecology of Amazonian chironomids (Diptera). Canadian Entomologist, 1971, 103(3), 407-413. http://dx.doi.org/10.4039/ Ent103407-3.

FRANÇA, J.S. and CALLISTO, M. Macroinvertebrados bentônicos como bioindicadores de qualidade de água: experiências em educação ambiental e mobilização social. Revista Extensão, 2012, 2, 197 206.

FROEHLICH, C.G. Some Gripopterygids and Notonemourines (Plecoptera) from South America. Lunds Universitets Arsskrift, 1960, 56, 3-24.

FROEHLICH, C.G. Studies on Brazilian Plecoptera 1. Some Gripopterygidae from the biological station at Paranapiacaba, state of Sao Paulo. Beiträge zur Neotropischen Fauna, 1969, 6(1), 17-39. http:// dx.doi.org/10.1080/01650526909360412.

KLEEREKOPER, H. Introdução ao estudo da Limnologia. Rio de Janeiro: Ministério da Agricultura, 1944.

MOTOYAMA, S.A. A gênese do CNPq. Revista da Sociedade Brasileira de Historia da Ciencia, 1985, 2, 27-46.

SPINAK, E. Indicadores cienciometricos. Ciência da Informação, 1998, 27(2), 141-148. http://dx.doi. org/10.1590/S0100-19651998000200006.

STRIXINO, G. and TRIVINHO-STRIXINO, S. Macrobentos da represa do Monjolinho (São Carlos-SP). Revista Brasileira de Biologia, 1982, 42, 165-170.

TAKEDA, A.M., SHIMIZU, G.Y. and HIGUTI, J. Zoobentos de uma lagoa marginal (Lagoa Fechada, Rio Baia, Alto Paraná). Ciencia e Cultura, 1990, 42(11), 1003-1007.

TRIVINHO-STRIXINO, S. and STRIXINO, G. Nova espécie do gênero Chironomus Meigen do sul do Brasil (Diptera: Chironomidae). Revista Brasileira de Entomologia, 1981, 25, 333-340.

US ENVIRONMENTAL PROTECTION AGENCY - USEPA. Volunteer stream monitoring: a methods manual. Washington: USEPA, 1997.

WALKER, I. Rede de alimentação de invertebrados das águas pretas do sistema Rio Negro. Observaçóes sobre a predação de uma Amoeba do tipo Amoeba discoides. Acta Amazonica, 1978, 8, 423-438.

WÜRDIG, N.L. and FREITAS, S.M.F. Distribuição especial e temporal da comunidade de ostracodes na Lagoa Emboaba, Rio Grande do Sul, Brasil. Acta Limnologica Brasiliensia, 1988, 2, 677-700.

Received: 30 June 2016 Accepted: 19 October 2016 